\title{
Begomoviruses Associated to Pepper Yellow Leaf Curl Disease in Thailand
}

\section{Chiemsombat $\mathrm{P}^{1 *}$, Srikamphung $\mathrm{B}^{2}$ and Yule $\mathrm{S}^{3}$}

${ }^{1}$ Department of Plant Pathology, Faculty of Agriculture at Kamphaeng Saen, Kasetsart University Kamphaeng Saen, Nakhon Pathom, Thailand

2Thailand vegetable research center, Department of Horticulture, Faculty of Agriculture at Kamphaeng Saen, Kasetsart University Kamphaeng Saen, Nakhon Pathom, Thailand

${ }^{3}$ Doctor of Philosophy Program in Agricultural Research and Development; Faculty of Agriculture at Kamphaeng Saen, Kasetsart University Kamphaeng Saen, Nakhon Pathom, Thailand

*Corresponding author: Pissawan Chiemsombat, Department of Plant Pathology, Faculty of Agriculture, Kamphaeng Saen Kasetsart University Kamphaeng Saen, Thailand, Tel: +66-0814132222; Email: agrpwc@ku.ac.th

\section{Abstract}

Yellow leaf curl disease (YLCD) of pepper has been re-emerging in most pepper production areas in Thailand causing serious damages to marketable yields. To develop resistant pepper variety for disease defence, the begomoviruses associated with YLCD were identified based on DNA-A nucleotide sequences. Field surveys for YLCD incidences were conducted in 10 provinces across the country during May 2012 to November 2014. YLCD was found to be distributed in most of the chili pepper production fields with varying degree of disease incidences, where the highest infection percentage was about 95\% in one field in Kanchanaburi province. Six isolates of YLC-pepper begomoviruses from 6 locations were isolated by using rolling circle amplification (RCA), and the obtained circular DNAs were cloned and sequenced. The cloned DNA-A sequences revealed characteristic of begomovirus associated to YLCD pepper with 90.490.7\% identical to those of previously reported records in GenBank database. Virus species were further identified using Sequence Demarcation Tool (SDT) program based on DNA-A component sequences, using the cut-off value at <91\%. Results indicated that five isolates were designated to be Pepper yellow leaf curl Thailand virus (PepYLCTHV), and one isolate was Tobacco leaf curl Thailand virus (TbLCTHV). This is the first report on the diverse genomes of begomoviruses infecting pepper in Thailand. The transmission rate of PepYLCTHV by whitefly, Bemisia tabaci Genn. From YLC-pepper to pepper seedlings was $100 \%$ under glasshouse condition, but the virus could not be transmitted to tomato seedlings. Both DNA-A and DNA-B components identity to PepYLCTHV were detected in a single whitefly body.

Keywords: Pepper Leaf Curl; Rolling Circle Amplification; DNA-A; DNA-B; Begomovirus; Whitefly Transmission 


\section{Open Access Journal of Agricultural Research}

\section{Introduction}

In the tropical and sub-tropical regions, the occurrence of several begomovirus species causes devastating losses to vegetable production, especially in pepper (chili pepper), tomato and cucurbits. Begomoviruses typically induce yellow leaf curl symptoms and retard plant growth. The diseases spread rapidly in the field due to efficient transmission by whiteflies (Bemisia tabaci Genn.). In Thailand, the most prevalent begomovirus infecting tomato had been identified as Tomato yellow leaf curl Thailand virus (TYLCTHV), followed by Tobacco leaf curl Thailand virus (TbLCTHV) [1,2]. TYLCTHV in Thailand possesses a bipartite genome and was efficiently transmitted by $B$. tabaci from tomato to tomato [3]. Other begomovirus species were also reported to infect various host plants in Thailand, including soybean, angled luffa, eggplant, cucumber, bottle gourd, muskmelon, pumpkin, wax gourd, okra and Sauropus [4-11]. However some of these reported begomoviruses were determined only for DNA-A sequence while the detection of DNA-B by polymerase chain reaction with universal DNA-B primers was unsuccessful [11].

Pepper is one of the most important vegetables traditionally consumed by Thai people for a very long time and its production areas increase every year. The YLCD of pepper has been observed since 1995 in Kanchanaburi province and the causal virus genome sequence was found to be distinct from the previously recorded begomoviruses [12]. The complete DNA-A sequence of the pepper infecting begomovirus was first deposited in GenBank database in 1999 and the provisional virus name was designated as Pepper leaf curl virus (AF134484). Recently yellow leaf curl disease has been re-emerging in most pepper production areas. Diseased plants showed striking yellow mosaic and leaf curl, or yellow veins and leaf curl. Young leaves were chlorotic and shoots were severely distorted. However, the genome corresponds to the virus that causes the disease has not been identified. In Southeast Asian countries such as Indonesia, chili pepper showing yellow leaf curl symptoms was diagnosed to be infected by Pepper yellow leaf curl Indonesia virus (PepYLCIV) $[13,14]$. The virus possesses bipartite genome and was experimentally transmitted by whiteflies from pepper to tomato and several other hosts including solanaceous and leguminous plants. A new strain of Tomato yellow leaf curl Kanchanaburi virus (TYLCKaV) of pepper plants emerged in northern Sumatra, Indonesia and the DNA-A sequence shared only $76 \%$ identity to PepYLCIV [15]. In the Philippines, two begomoviruses detected in diseased pepper plants were Tomato leaf curl Philippine virus and Tomato leaf curl Cebu virus [16]. In Taiwan the causal virus of leaf curl disease of pepper shared $99 \%$ identity to TYLCTHV for both DNA-A and DNA-B [17]. These reports suggested the diversity of pepper infecting begomoviruses and YLCD complex in Asian region.

To develop peppers resistant to YLCD in Thailand, the causal begomovirus must be precisely identified so that the resistance genes and germplasm resources can be evaluated against the causal viruses. Hence, the objectives of this study were to identify the begomovirus infecting YLC-chili pepper plants in Thailand based on DNA-A sequence, determine virus genetic diversity and relationship, and study whitefly transmission.

\section{Material and Methods}

\section{Field Survey and Sample Collection}

The YLCD survey was conducted from May 2012 to November 2014 encompassing the north, northeast, central, west and southern parts of Thailand. Disease incidence in each location was evaluated by visual observation of YLC symptom, plants diagnosed by ELISA using locally prepared monoclonal antibodies of begomovirus species found in Thailand (kindly provided by the Department of Plant Pathology, Kasetsart University, Kamphaeng Saen, Thailand). The percentage of diseased plants was estimated in a small area of about 50-100 plants per field representative of each location. Begomovirus detection was performed by PCR for partial genome amplification, followed by direct sequencing. For species identification, leaves of six symptomatic pepper plants typical of YLCD were collected from different location of production fields in Suphanburi, Kanchanaburi, Khon Khaen, Chiangmai and Patthalung provinces during May 2012 to November 2014. For DNAA sequence determination, circular DNAs present in the samples were amplified by rolling circle amplification [18], followed by DNA cloning and sequencing [19].

\section{DNA Extraction and Viral Genome Amplification}

Total DNA was extracted from collected pepper leaves following Kawata et al [20]. In brief, leaf tissue $(0.01 \mathrm{~g})$ was ground in $250 \mu \mathrm{l}$ of $60^{\circ} \mathrm{C}$ extraction buffer (3\% CTAB, $0.1 \mathrm{M}$ Tris $\mathrm{HCl}, \mathrm{pH} 8.0,0.02 \mathrm{M}$ EDTA pH $8.0,1.4 \mathrm{M} \mathrm{NaCl}$, $28.6 \mathrm{mM}$ mercaptoethanol), and plant sap was transferred to $1.5 \mathrm{ml}$ tubes to incubate at $60^{\circ} \mathrm{C}$ for $30 \mathrm{~min}$. An equal volume of chloroform: isoamyl alcohol (24:1) was added and mixed thoroughly, followed by centrifugation at 6000 rpm for 5 min. The supernatant was transferred to new 


\section{Open Access Journal of Agricultural Research}

tubes, 0.7 volume of isopropanol was added and tubes were kept at $-20^{\circ} \mathrm{C}$ for $15 \mathrm{~min}$. Total DNA was collected by centrifugation at $13000 \mathrm{rpm}$ for $15 \mathrm{~min}$, washed with $70 \%$ ethanol, air dried and suspended with $20 \mu$ sterile distilled water.

Diagnosis of begomovirus infecting YLC-pepper from fields was performed by PCR using degenerate primers PALV1978/PARC496, which would yield 1307 nucleotide (nts) fragment of half-length DNA-A [21]. Sequences of randomly selected eighteen DNA fragments were determined and all showed characteristic of begomovirus DNA-A. Full length DNA-A molecules from six samples of YLC-pepper were amplified according to the RCA procedure previously described using the Templiphi 100 Amplification kit (GE Healthcare, USA) [18]. The obtained DNA products were subjected to each restriction enzyme digestion (BamHI, HindIII, KpnI, PstI) to produce linearized full length circular genome components. Digested viral DNAs were cloned into pQE80L plasmid vector (Qiagen, Germany). To complete full length (approx. 2750 nts) DNA-A sequencing, the inserted DNA was bidirectional sequenced using T7 and SP6 primers. To fill gaps between the flanking sequences of DNA-A, the walking primer, WBegoCP-F: 5' GAAGCTGGGAAGTATGA GAACC 3' were designed for direct sequencing of the regions between T7-forward and SP6-reverse fragment sequences of each clones. Sequences were assembled using the DNASeqMan program (Lasergene, USA). Coat protein gene specific primers were also used for sequencing of DNA-A positive clones. The same sequencing strategy was applied for DNA-B sequencing from RCA-based clones with gap filling sequencing primer PCRc154, 5' CTAGCTGCAGCATATTTACRARWATGCCA 3' [21]. In addition, to detect DNA-B component in the samples, amplification was also performed by PCR with degenerate primers, PBLv2040 5'GCTCTGCAGCARTGRTCKATCTTCCATACA 3', and PCRc154 5' CTAGCTGCAGCATATTTACRARW ATGCCA 3' [21], using total DNA extracted from all collected samples. PCR products were analyzed in $0.8 \%$ agarose gel electrophoresis.

\section{Virus Identification and Phylogenetic Analysis}

Identification of begomovirus DNAs from six isolates of the YLC-chili pepper was firstly determined by Blast program via URL: http://www.ncbi.nlm.nih.gov./blastn. Multiple alignment of the relevant DNA-A sequences was done by ClustalW via URL: http://ebi.ac.uk/ClustalW [22] or Megalign program (Lasergene) to compare with other full DNA-A sequences of begomoviruses infecting pepper, tomato tobacco and other hosts in Thailand and some
Asian countries, which were available from GenBank database (Table1). Finally, begomovirus species names were designated based on results of pair wise sequence comparison of full length DNA-A using the Sequence Demarcation Tool (SDT) v1.2 software [23] and guideline provided by Brown et al [24]. Phylogenetic analysis was performed by the neighbor-joining method using MEGA program [25].

\section{Whitefly Characterization}

The whitefly genetic group was determined using mitochondrial COI gene sequences derived from PCRamplification [26]. The whiteflies, collected from the Tropical Vegetable Research Centre experimental fields, were placed in $70 \%$ ethanol and individually processed for total DNA extraction using the same procedure of plant DNA extraction as above. For COI gene amplification, primers C1-J-2195 (5'TTGATTTTTTGGTCATCCAGAAGT-3') and L2-N-3014 (5'TCCAATGCACTAATCT GCCATATTA-3') were used [27] with DNA template obtained from individual whiteflies and mixed with PCR master mixture for amplification. PCR products of expected size were directly sequenced and the phylogenetic relationship was analyzed [28].

\section{Whitefly Transmission of YLC Begomovirus in Pepper}

Investigation for transmission of YLC-associated begomovirus was performed in December 2014 using the whitefly B. tabaci. The whiteflies were collected from the experimental tomato field of the TVRC, Kasetsart University Kamphaeng Saen campus, Nakhon Pathom province, in November 2014. Whiteflies were primarily reared on Chinese kale plants (Brassica alboglabra L.H. Bailey), and kept in an insect-proof cage. Newly laid eggs were transferred onto healthy Thai eggplant (Solanum xanthocarpum Schrad \& H. Wendl) for multiplying nonviruliferous whitefly colonies in insect-proof cages. YLCpepper plants were propagated in our laboratory by whitefly inoculation on pepper seedlings and symptomatic pepper plants were used as virus sources in transmission test. TYLCTHV which infected tomato was isolated from YLC-tomato from Suphanburi province and identified by RCA-based cloning and sequencing. It was 96.63\% identical to TYLCTHV - TH (AF141922). This TYLCTHV isolate, SPN-T1 (KT322144) was then used for comparative transmission trial of TYLCTHV to pepper and tomato.

Two mass transmission trials were completed in an air-conditioned glasshouse at a temperature of $25-28^{\circ} \mathrm{C}$. Three symptomatic YLC-chili pepper plants were placed 


\section{Open Access Journal of Agricultural Research}

in a cage for 2 weeks before transferring more than 100 non-viruliferous whiteflies onto these plants and then they were allowed to feed for at least $2 \mathrm{wk}$. The whiteflies could move and multiply freely in this cage. Target plants were fifteen 14-day-old seedlings of each chili pepper, Capsicum annuum cv. TVRC758, and tomato, Solanum lycopersicum cv. Seedathip4 (kindly provided by TVRC, Kasetsart University). Two trays each containing 15 pepper or tomato seedlings were placed in the same insect cages which contained diseased chili pepper plants and more than one hundred viruliferous whiteflies. After $48 \mathrm{~h}$ of the inoculation period, both seedling trays were removed from the feeding cage; insecticide was sprayed to eradicate whiteflies, and the seedling trays were placed in an insect-free cage. A week later, all seedlings were individually transplanted into 4-in. pots of humic soil and kept in insect-proof cages in the air-conditioned glasshouse at a temperature of $27-29^{\circ} \mathrm{C}$ for symptom observation for 1 month. The second trial was conducted after the first trial-seedlings were removed from virus inoculation cage. A control experiment was performed in the same way but using healthy chili pepper plants and non-viruliferous whiteflies. The presence of the virus in inoculated seedlings was confirmed by PCR using degenerate primer pairs PALV496/PARC496 and followed by nucleotide sequencing.

\section{Results and Discussion}

\section{Plant Symptoms and Disease Incidence}

The YLCD incidences were evaluated from eighteen representative fields in Suphanburi (central), Kanchanaburi (west), Nakhon ratchasima (northeast), Ubon Ratchathani (northeast), Sisaket (northeast), Khon Kaen (northeast), Chiangmai (north), Songkhla (south), and Phatthalung (south). YLCD appeared in most of chili pepper growing areas with striking symptoms included yellow mosaic of leaves, leaf distortion and small size leaves at plant apices (Figure 1). Fruits became pale green or yellow and were deformed. YLCD was obviously distributed in most production fields of chili pepper with varying degree of disease incidences. The highest infection percentage of about $95 \%$ was found in one field in Kanchanaburi province while another field in this province showed only 30\% infection (Table 1). The primary diagnosis of begomoviruses by PCR using degenerate primers PALV496/PARC496 yielded 1307 nucleotide DNA fragments which showed characteristics of begomovirus gene region of partial Rep and CP coding sequences. The common region stem-loop structure showed identical nonanucleotide loop (TAATATTAC), which confirmed for the presence of begomoviruses in all YLC plant samples.

\begin{tabular}{|c|c|c|c|c|c|}
\hline Date (dd-mm-yy) & Area & Province & District & $\begin{array}{c}\text { No. of fields } \\
\text { surveyed }\end{array}$ & $\begin{array}{c}\text { Visual disease } \\
\text { incidence (\%) }\end{array}$ \\
\hline $11 / 10 / 2012$ & Northeast & Nakhon ratchasima & Dan Khun Tod & 2 & $60-80 \%$ \\
\hline $13 / 10 / 2012$ & West & Kanchanaburi & Ta Ma Ka & 2 & $30-95 \%$ \\
\hline $1 / 12 / 2012$ & Northeast & Ubon Ratchathani & Muang & 4 & $10-20 \%$ \\
\hline $2 / 12 / 2012$ & Northeast & Sisaket & Muang & 4 & $5-50 \%$ \\
\hline $21 / 12 / 2012$ & Central & Suphanburi & Song Phi Nong & 1 & $50 \%$ \\
\hline $21 / 12 / 2012$ & Central & Suphanburi & U Thong & 3 & $30-70 \%$ \\
\hline $6 / 3 / 2013$ & South & Songkhla & Ra Not & 1 & $10 \%$ \\
\hline $7 / 3 / 2013$ & South & Phatthalung & Kuan Khanoon & 1 & $30 \%$ \\
\hline $2 / 11 / 2014$ & Northeast & Khonkaen & Muang & 1 & $30 \%$ \\
\hline $5 / 11 / 2014$ & North & Chiangmai & Sansai & 2 & $10-20 \%$ \\
\hline
\end{tabular}

Table 1: Incidence of pepper yellow leaf curl disease (YLCD) in Thailand as determined by visual symptoms in a 2012-14 field survey. 


\section{Open Access Journal of Agricultural Research}

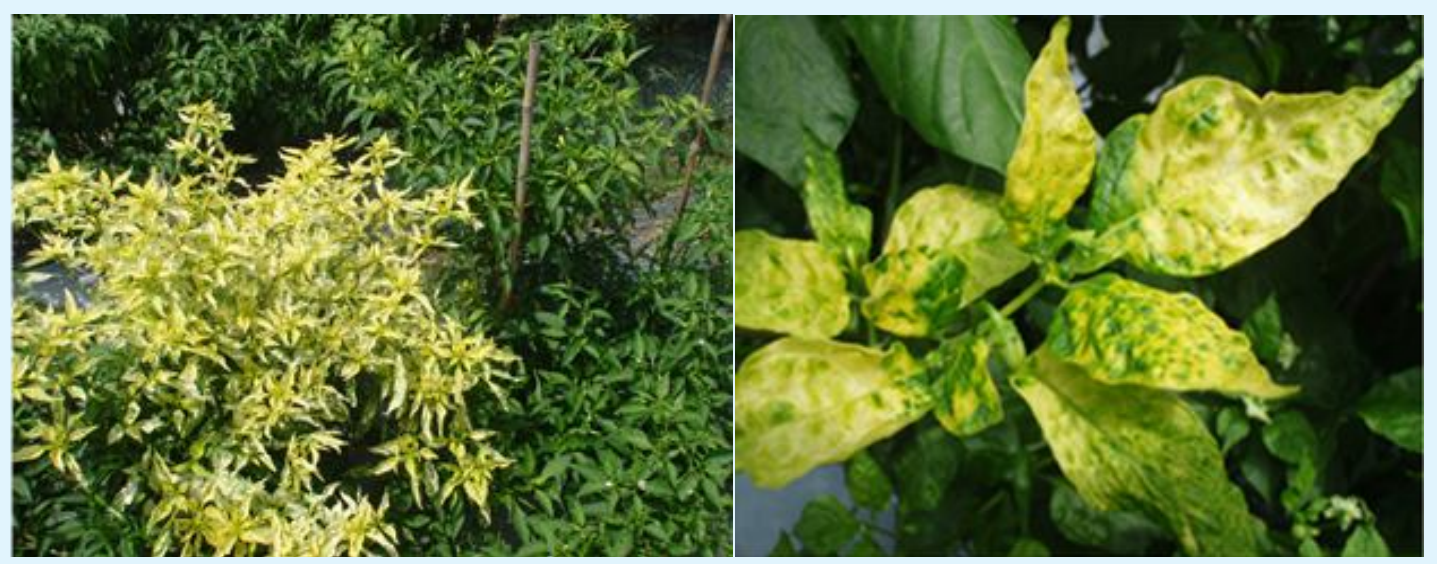

Figure 1: Yellow leaf curl disease symptom on Capsicum annuum found in pepper growing field in Kanchanaburi province in 2014 (left), and isolate PG1 from Suphanburi province in 2012 (right).

Incidence of yellow leaf curl disease of chili pepper in Thailand has been reported for years but virus diagnosis was performed mostly by ELISA using an antibody, which broadly detects begomoviruses but is not specific to PepLCV or PepYLCV. In practice, YLCD symptoms are easily recognizable by its striking yellow mosaic leaf and plant stunting, but using nonspecific antibodies may suggest a false diagnosis of the causal virus species. This indicates the importance of accurate virus identification and precise diagnosis of the YLCD-causal viruses to understand the spread and genetic structure of the begomovirus species in diseased chili pepper. In our study disease incidences varied across the surveyed locations, and symptoms may be slightly different probably depending on different plant varieties, or plant ages or mixed infection of multiple viruses. We could not detect TYLCTHV in pepper samples in our survey and diagnosis protocols. These results suggested that most of begomoviruses found in Thailand co-evolved with their primary hosts, i.e. Solanaceous, Cucurbitaceous, and Malvaceous crops and whitefly may play significant role in virus transfer to new host species but to infect the new host depend on genetic adaptation of the viruses [29].

\section{DNA-A Genome and Virus Identification}

Circular DNA-A sequences of the five isolates of YLC pepper contained 2746 nucleotides for isolates PG1 (Suphanburi), KG5 (KhonKaen), KR5 (Kanchanaburi), KR8 (Kanchanaburi) and KKN13 (Patthalung), except isolate CM5 (Chiangmai), which contained 2733 nucleotides. All DNA-A components contained six ORFs, AV1, AV2 on the virion sense sequence, $\mathrm{AC} 1, \mathrm{AC} 2, \mathrm{AC} 3$, and AC4 on the complementary sense sequence, typical characteristic of begomovirus DNA-A. The stem-loop region contained 31- nt, the nonanucleotide-TAATATTAC and iterons -GGGGA, GGGGT. Coat protein gene of begomovirus isolates from YLC- pepper contained 774 nts coded for 258 amino acid residues with one additional amino acid residue position 100N (Asparagine), while it was $771 \mathrm{nts}$ and 257 amino acid residues in TYLCTHV coat protein.

Multiple sequence alignment by Megalign program to compare our discovered isolates of PepYLCTHV with the other selected begomoviruses indicated that the local five isolates- PG1, KG5, KR5, KR8 and CM5 shared 91.6-98.9\% identity among them while they shared less than $91 \%$ to the existed sequences of DNA-A of pepper begomovirus records deposited in GenBank (Table 2). The most identity to PepLCV record from Thailand in 1999 (AF134484) was only 88.3\%. Another isolate, KKN13 (Phatthalung), had $73.0 \%$ identity to the other isolates, and shared $90.7 \%$ identity to TbLCTHV isolate AIT from tomato. Pairwise comparison of DNA-A sequences and identification using the SDT program with a $<91 \%$ cut off value revealed the colored code indication that the isolates PG1, KR5, KR8, KG5 and CM5 were distinct from the previously reported species. Therefore, they were newly designated as Pepper yellow leaf curl Thailand virus (PepYLCTHV) in relevant to the striking yellow leaf curl symptoms of diseased plants and based on nomenclature guideline [24]. Based on pairwise sequence analysis by SDT, isolate KKN13 was named as TbLCTHV.

\section{Phylogenetic Analysis of DNA-A Sequences}

Neighbour-joining tree reconstruction of most of the begomoviruses found in Thailand and some other Asian countries with our studied isolates exhibited the distinct clusters of PepYLCTHV begomovirus associated to chili 


\section{Open Access Journal of Agricultural Research}

pepper in this study from previous PepLCV isolates with $100 \%$ bootstrapping value (Figure 2). All isolates of PepLCTHV showed closed branch to TYLCTHV but distant branches to begomoviruses associated with Sauropus and Cucurbitaceous plants. The KKN13 isolate formed the cluster together with TbLCV and TbCSV isolates and closed branching to TYLCTHV from tomato. Among the begomoviruses presented in Thailand, TYLCKaV from tomato and eggplant showed its uniqueness of individual branching.

The YLC begomovirus DNA-A under this study were closely related to PepLCV, TYLCTHV and TbLCTHV which had been reported in Thailand $[1,2,4]$. In addition, there have been new GenBank deposited records of Eggplant golden mosaic virus (KU569586, KU569598, KU569601) from eggplant in Thailand shared up to $90.4-99.2 \%$ to our five virus isolates, suggesting that they were the same species, but $90.5 \%$ identity to DNA-A of TbCSV isolate YN4524 from tomato in Yunnan China $[10,30,31]$. Different isolates of TYLCTHV, TbCSV and TbLCTHV in China shared various identity levels to TbLCTHV isolate KKN13 in our study. Its relation to TbCSV in detail such as biology and ecology needs further investigation.

\section{Detection of DNA-B Component}

Our attempts to detect DNA-B in leaf samples of YLCchili pepper by PCR using universal primers PBLv2040/PCRc154 were unsuccessful. However, when applied RCA-based cloning, two samples of YLC-chili pepper each in Kanchanaburi (KR8B) and Khon Kaen (KG5B) provinces were diagnosed to contain circular component with typical characteristics of begomovirus DNA-B. The PepYLCTHV isolate KR8B consisted of 2730 (KX885224) and KG5B consisted of 2731 nts (KX885225). The 206 nts common region (CR) sequences of both DNAB were $86.25 \%$ identical. The two ORFs, BR1 and BL1 proteins, in each of DNA-B molecule shared most protein identity to BV1 and BC1 proteins of TYLCKaV at 86 and
91\%, respectively. Each DNA-B isolate shared $82.5 \%$ identity to the common region sequence of the DNA-A from its cognate isolate, indicating the potential of corresponding bipartite components. The detection for DNA-B in isolate KKN13 was failed while using our PCR conditions.

Most of the begomoviruses found in Thailand possess bipartite genomes but the routine detection of DNA-B has been relatively more difficult than the detection of DNA-A. The RCA method provided advantages in amplifying circular viral genome in the samples and facilitate the cloning of mono- or bi-partite virus genomes from either plant tissue or whitefly body [24,32]. In Indonesia both monopartite and bipartite begomoviruses causing leaf curl in chili pepper were reported and artificial inoculation of chili pepper with DNA-A and DNA-B of PepYLIV had been confirmed in disease induction $[13,14,33,34]$. Our research results suggested that YLCD of chili pepper in Thailand is disease complex, potentially associated with at least three species of begomovirus, with bipartite genomes. Determination for the corresponding DNA-B of PepLCTHV isolates from Thailand in disease development on pepper as well as the role of DNA-Bs in YLCD symptoms remain to be determined. There were many begomovirus species reported to cause epidemic diseases in the tropical and subtropical regions of the world, and virus genetic variation was not geographically-associated for instance TYLCTHV, ToLCNDV, or SLCCNV occurred in several countries [24]. In case of pepper leaf curl associated viruses, more diversity was observed and there appeared that some distinct species were restricted to the corresponding geographical regions, such as Pepper yellow leaf curl Indonesia virus, Tomato leaf curl Philippine virus and Tomato leaf curl Cebu virus, including Pepper yellow leaf curl Thailand virus identified in Indonesia, Philippines, Cebu, and Thailand, respectively.

\begin{tabular}{|c|c|c|c|c|c|c|}
\hline Virus species, Acronym & Isolates & Accession no. & Crop & Year Collected & Country & Reference \\
\hline \multirow{4}{*}{$\begin{array}{c}\text { Ageratum yellow vein } \\
\text { virus, AYVV }\end{array}$} & AFSP1a & JN809811 & \multirow{4}{*}{$\begin{array}{c}\text { Sweet leaf bush } \\
\text { (Sauropus } \\
\text { androgynous) }\end{array}$} & \multirow{4}{*}{2010} & \multirow{4}{*}{ Thailand } & \multirow{4}{*}[11]{} \\
\hline & AFSP2a & JN809812 & & & & \\
\hline & AFSP2b & JN809813 & & & & \\
\hline & AFSP6b & JN809820 & & & & \\
\hline \multirow{2}{*}{$\begin{array}{l}\text { Bhendi yellow vein } \\
\text { mosaic virus, BYVMV }\end{array}$} & Ok2 & JX678966 & Okra & 2009 & \multirow{2}{*}{ Thailand } & \multirow{2}{*}[10]{} \\
\hline & WTHOK6 & JX678967 & Okra & 2009 & & \\
\hline \multirow{2}{*}{$\begin{array}{l}\text { Eggplant golden } \\
\text { mosaic virus, EGMV }\end{array}$} & TH14E2-1 & KU569598 & \multirow{2}{*}{ Eggplant } & 2012 & \multirow{2}{*}{ Thailand } & \multirow{2}{*}[6]{} \\
\hline & TH14E3-5 & KU569601 & & 2012 & & \\
\hline
\end{tabular}

Chiemsombat $\mathrm{P}$, et al. Begomoviruses Associated to Pepper Yellow Leaf Curl Disease in Thailand. J Agri Res 2018, 3(7): 000183. 


\section{Open Access Journal of Agricultural Research}

\begin{tabular}{|c|c|c|c|c|c|c|}
\hline & TH12WE12 & KU569586 & & 2012 & & \\
\hline $\begin{array}{l}\text { Pepper leaf curl virus- } \\
\text { Thailand, PepLCTHV }\end{array}$ & \begin{tabular}{c|} 
Kan- \\
pepper1999
\end{tabular} & AF134484 & Pepper & 1999 & Thailand & [12] \\
\hline \multirow{5}{*}{$\begin{array}{l}\text { Pepper yellow leaf } \\
\text { curl Thailand virus, } \\
\text { PepYLCTHV }\end{array}$} & KG5 & KT322141 & \multirow{5}{*}{ Pepper } & 2014 & \multirow{5}{*}{ Thailand } & \multirow{5}{*}{ This study } \\
\hline & KR5 & KT322145 & & 2014 & & \\
\hline & KR8 & KT322146 & & 2014 & & \\
\hline & CM5 & KT322142 & & 2014 & & \\
\hline & PG1 & KT322143 & & 2012 & & \\
\hline $\begin{array}{c}\text { Pepper yellow leaf } \\
\text { curl Indonesia virus, } \\
\text { PepYLCIV }\end{array}$ & Bogor & DQ083764 & Pepper & 2005 & Indonesia & [13] \\
\hline \multirow{2}{*}{$\begin{array}{c}\text { Squash leaf curl China } \\
\text { virus, SLCCNV }\end{array}$} & PK & EU543562 & Pumpkin & 2008 & \multirow{2}{*}{ Thailand } & \multirow{2}{*}{ [8] } \\
\hline & WG & AB330078 & Wax gourd & 2007 & & \\
\hline $\begin{array}{c}\text { Sauropus leaf curl } \\
\text { virus, SauLCuV }\end{array}$ & AFSP5e & JN809819 & Sweet leaf bush & 2010 & Thailand & {$[11]$} \\
\hline $\begin{array}{c}\text { Tobacco curly shoot } \\
\text { virus, TbCSV }\end{array}$ & YN4524 & KU934096 & Tomato & 2014 & China & [30] \\
\hline \multirow{2}{*}{$\begin{array}{c}\text { Tobacco leaf curl } \\
\text { Thailand virus, } \\
\text { TbLCTHV } \\
\end{array}$} & AIT & DQ871222 & Tomato & 2006 & \multirow{2}{*}{ Thailand } & [2] \\
\hline & KKN13 & KT322140 & Pepper & 2013 & & This study \\
\hline \multirow{5}{*}{$\begin{array}{l}\text { Tomato leaf curl New } \\
\text { Delhi virus, ToLNDV }\end{array}$} & KPS-Lf & AF102276 & Luffah & 1998 & \multirow{5}{*}{ Thailand } & [5] \\
\hline & KPS-C & AB330079 & Cucumber & 2007 & & [7] \\
\hline & KPS-B & AB368447 & Bottle gourd & 2007 & & [7] \\
\hline & KPS-M & AB368448 & Muskmelon & 2007 & & {$[7]$} \\
\hline & AFSP2 & JN809814 & Sauropus & 2010 & & [11] \\
\hline \multirow{3}{*}{$\begin{array}{c}\text { Tomato yellow leaf } \\
\text { curl Kanchanaburi } \\
\text { virus, TYLCKaV }\end{array}$} & TH-Kan1 & AF511529 & Tomato & 2001 & \multirow{3}{*}{ Thailand } & {$[6]$} \\
\hline & TH-Kan2 & AF511530 & Eggplant & 2001 & & {$[6]$} \\
\hline & TH12E5 & KU569584 & Eggplant & 2012 & & [10] \\
\hline \multirow{2}{*}{$\begin{array}{c}\text { Tomato yellow leaf } \\
\text { curl Kanchanaburi } \\
\text { virus, TYLCKaV }\end{array}$} & BA-B6 & LA051116 & Pepper & 2012 & Indonesia & [15] \\
\hline & Laos & KF218820 & Eggplant & 2010 & Lao PDR & [15] \\
\hline \multirow{5}{*}{$\begin{array}{l}\text { Tomato yellow leaf } \\
\text { curl Thailand virus, } \\
\text { TYLCTHV }\end{array}$} & NP-TH2 & AF141922 & Tomato & 1991 & \multirow{5}{*}{ Thailand } & [1] \\
\hline & Chiangmai & AY514630 & Tomato & 2003 & & [8] \\
\hline & $\begin{array}{c}\text { Sakon } \\
\text { Nakhon }\end{array}$ & AY514632 & Tomato & 2003 & & [8] \\
\hline & NongKai & AY514631 & Tomato & 2003 & & {$[8]$} \\
\hline & SPN-T1 & KT322144 & Tomato & 2012 & & This study \\
\hline \multirow{4}{*}{$\begin{array}{c}\text { Tomato yellow leaf } \\
\text { curl Thailand virus, } \\
\text { TYLCTHV }\end{array}$} & H6-4 & GU723749 & Tomato & 2007 & \multirow{4}{*}{ Taiwan } & [16] \\
\hline & AFP2-4 & EU249457 & Pepper & 2007 & & [11] \\
\hline & LG6-2 & GU208515 & Pepper & 2009 & & [17] \\
\hline & SG4-3 & GU208517 & Pepper & 2009 & & [17] \\
\hline \multirow{2}{*}{$\begin{array}{c}\text { Tomato yellow leaf } \\
\text { curl Thailand virus, } \\
\text { TYLCTHV }\end{array}$} & MM & AF206674 & Tomato & 1999 & Myanmar & Unpublished \\
\hline & Y72 & GU723749 & Tomato & 2002 & China & [30] \\
\hline
\end{tabular}

Table 2: List of the studied begomoviruses from pepper with full genome DNA-A sequences (Bold) and the retrieved begomovirus sequence accession numbers (GenBank database) used in multiple alignment and phylogenetic analysis. 


\section{Open Access Journal of Agricultural Research}

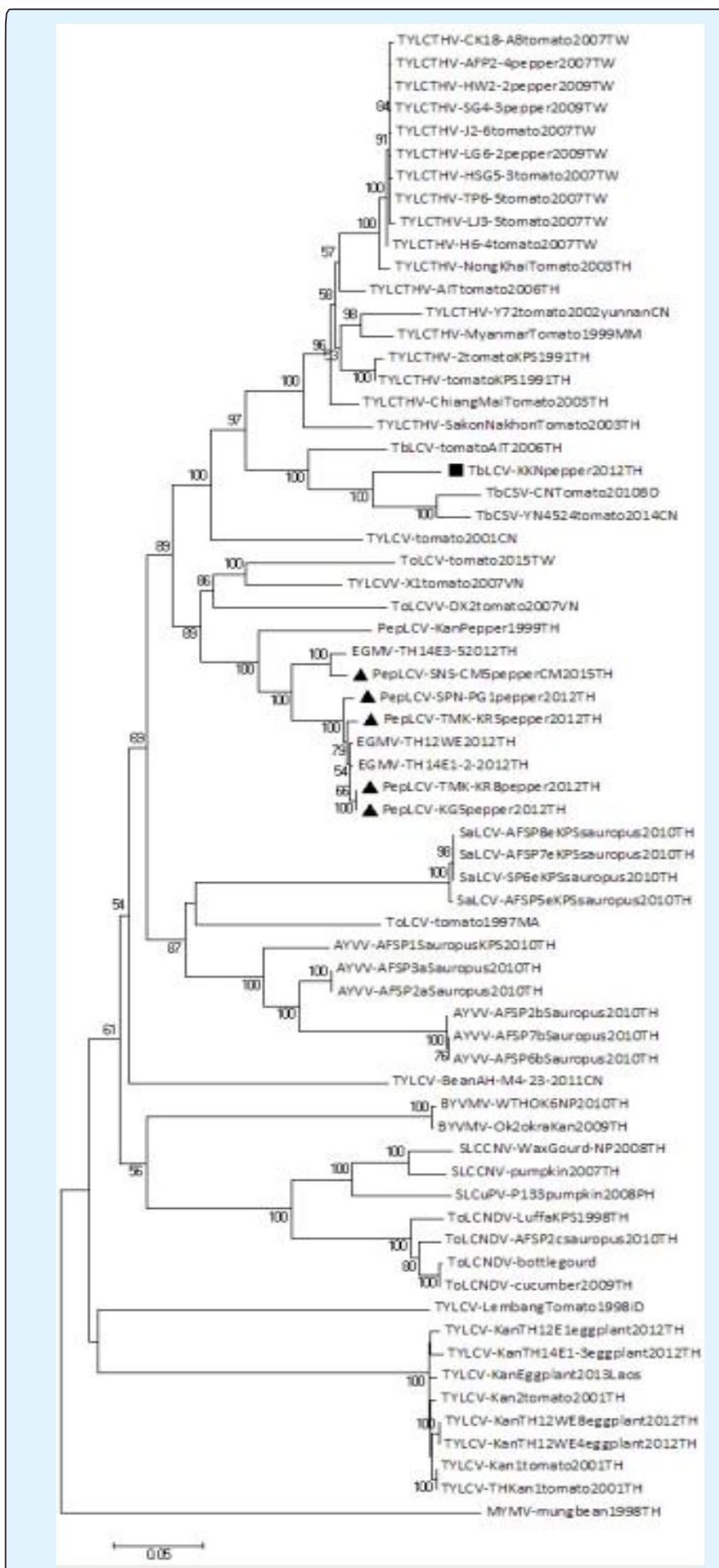

Figure 2: Phylogenetic neighbor-joining tree reconstructing from full DNA-A sequence distances obtained by pairwise alignment with the selected begomoviruses by MEGA analysis with 1000 bootstrap replications. Begomovirus isolates in this study are indicated with dark blocks. See virus name abbreviations and accession numbers under this study in Table 2.

\section{Whitefly Characterization and Virus Transmission}

PCR amplification of the COI gene from the collected whiteflies showed the expected 852 nts DNA fragment. Sequence analysis indicated that the whiteflies collected from the TVRC experimental field and used for transmission test, were classified in the genetic group Asia I $[26,35]$. One of pepper whitefly-COI gene sequences (KX865954) was 100\% identical to those of Asia I whitefly collected from pepper in Nakhon Pathom as reported previously [36].

Mass transmission of PepYLCTHV (PG1) with viruliferous whiteflies was highly efficient producing $100 \%$ and $83.3 \%$ symptomatic pepper plants in trials 1 and 2, respectively. Pepper seedlings showed typical YLC symptoms within 14-28 day post-inoculation (Table 3). PCR and sequencing confirmed that all symptomatic pepper plants were infected with PepYLCV and thus proving that PepYLCTHV is one of causative agents of YLCD in chili pepper. In contrast, none of the tomato plants in trials 1 and 2 developed disease symptom. No PepYLCTHV-DNA was detected by PCR. Confirmation for the presence of PepYLCV, both DNA-A and DNA-B in viruliferous single whitefly by RCA-based cloning and sequencing were positive. The virus genomes isolated from viruliferous whitefly were named WF-PepYLCTHV DNA-A containing 2742 bp (KX943290), and WF PepYLCTHV DNA-B containing 2732 bp (KX943291). Parallel transmission trials of TYLCTHV-[SPN-T1] resulted in $100 \%$ and $66.7 \%$ symptomatic tomato plants in trials 1 and 2, respectively. Tomato seedlings showed typical YLCD symptoms within 7-10 d post-inoculation. However only a single asymptomatic pepper seedling in trial 1 was diagnosed to contain TYLCTHV by PCR and sequencing.

Transmissibility of PepYLCTHV by whitefly to chili pepper was high but rare to tomato. In contrast TYLCTHV could be transmitted by whitefly to chili pepper but plants were symptomless. Morilla et al [37] reported that TYLCV could infect selected cultivar of $C$. annuum but unable to transmit TYLCV from pepper to tomato and concluded that pepper is a dead-end host of TYLCV. Polston et al [38] found that some genotypes of $C$. baccatum, $C$. chinense, $C$. annuum and $C$. frutescens but not $C$. pubescens, were susceptible to TYLCV and pepper might serve as reservoir for the transmission of TYLCV. Increasing the number of viruliferous whiteflies in transmission test increased transmission efficiency to susceptible pepper genotypes. Our results reflected the restricted host of PepYLCV in Thailand and potential to manage whitefly population to 


\section{Open Access Journal of Agricultural Research}

reduce field incidences of YLCD in pepper and tomato. Further test of eggplant as an alternate host of PepYLCTHV is under consideration. that are predominantly present in pepper plants in Asian regions were found to be Asia 1 based on mtCOI gene sequences $[28,35]$ while the YLCD causing begomoviruses in pepper and tomato were very diverse [39].

\begin{tabular}{|c|c|c|c|c|c|c|c|c|}
\hline \multirow{2}{*}{ Trial } & \multirow{2}{*}{ Host of inoculum } & \multirow{2}{*}{ Virus } & \multicolumn{3}{|c|}{$\begin{array}{c}\text { C. annuum seedling } \\
\text { (cv. TVRC758) }\end{array}$} & \multicolumn{3}{c|}{$\begin{array}{c}\text { S. lycopersicum seedling } \\
\text { (cv. Seedathip4) }\end{array}$} \\
\cline { 4 - 9 } & & & Tested & Infected & \% & Tested & Infected & \% \\
\hline 1 & Pepper & PepYLCTHV & 15 & 15 & 100 & 15 & 0 & 0 \\
\hline 2 & Pepper & PepYLCTHV & $12^{1 /}$ & 10 & 83.3 & 15 & 0 & 0 \\
\hline 1 & Tomato & TYLCTHV & $11^{1 /}$ & 1 & 9.09 & 15 & 15 & 100 \\
\hline 2 & Tomato & TYLCTHV & 15 & 0 & 0 & 15 & 10 & 66.7 \\
\hline
\end{tabular}

1/ Plants died after being transferred to growing pots.

Table 3: Result on trials on transmission of Pepper yellow leaf curl Thailand virus, PepYLCV (isolate PG1, this study) by whiteflies, Bemisia tabaci Genn., from diseased pepper plants to seedlings of Capsicum annuum (cv.TVRC758) and Solanum lycopersicum (cv. Seedathip4) in comparison with transmissibility of Tomato yellow leaf curl Thailand virus, TYLCTHV (isolate SPN-T1, this study).

\section{Conclusion}

Our results indicated the nature of mixed infection or disease complex of pepper YLCD in Thailand. The RCAbased cloning enhanced the possibility for detection and harnessing of circular genomes of mixed begomovirus species in chilli pepper leaves and whitefly body. Transmission rate of PepYLCTHV by B. tabaci to chili pepper was high up to $100 \%$ but rare to tomato and vice versa in laboratory conditions. The experiment for inoculation of DNA-A and DNA-B of KG5 or KR8 isolates of PepYLCTHV is needed to elucidate the YLC-causal begomovirus, as well as the role of its cognate DNA-B.

\section{Acknowledgement}

This research was partially supported by a grant for graduate students from Kasetsart University with cofinancing by Thailand Research Fund Organization (RDG5620003) in Thailand.

\section{Competing Interests}

Authors have declared that no competing interests exist.

\section{Authors Contributions}

PC designed the study and performed the sequence analysis, wrote the protocol, and wrote the first draft of the manuscript. BS performed field survey, PCR and RCAbased virus gene cloning and sequencing. SY performed whitefly biotyping and conducted transmission trials. All authors read and approved the final manuscript.

Chiemsombat $\mathrm{P}$, et al. Begomoviruses Associated to Pepper Yellow Leaf Curl Disease in Thailand. J Agri Res 2018, 3(7): 000183.

\section{References}

1. Attathom S, Chiemsombat P, Kositratana W, Sae-Ung N (1994) Complete nucleotide sequence and genome analysis of bipartite tomato yellow leaf curl virus in Thailand. Kasetsart J (Nat Sci) 28: 632-639.

2. Knierim D, Maiss E (2007) Application of Phi29 DNA polymerase in identification and full-length clone inoculation of Tomato yellow leaf curl Thailand virus and Tobacco leaf curl Thailand virus. Arch Virol 152(5): 941-954.

3. Thongrit D, Attathom S, Sutabutra T (1986) Tomato yellow leaf curl virus in Thailand. In: Plant Virus Diseases of Horticultural crops in the Tropics and Subtropics. FFTC Book series no. 33. Taipeii Taiwan, Republic of China

4. Samretwanich K, Kittipakorn K, Chiemsombat P, Ikegami M (2001) Complete nucleotide sequence and genome organization of Soybean crinkle leaf virus. J Phytopathol 149(6): 333-336.

5. Tantiwanich Y, Chiemsombat P (2002) Gene Cloning and Genome structure of geminivirus causing yellow leaf curl disease of angled luffa. Thai Phytopathol 16: $1-14$.

6. Green S, Tsai W, Shih S, Rezaian M, Duangsong U (2003) Molecular characterization of a new Begomovirus associated with tomato yellow leaf curl 


\section{Open Access Journal of Agricultural Research}

and eggplant yellow mosaic diseases in Thailand. Plant Dis 87(4): 446.

7. Ito T, Sharma P, Kittipakorn K, Ikegami M (2008) Complete nucleotide sequence of a new isolate of Tomato leaf curl New Delhi virus infecting cucumber, bottle gourd and muskmelon in Thailand. Arch Virol 153(3): 611-613.

8. Sawangjit S (2009) The complete nucleotide sequence of Squash leaf curl China virus-[wax gourd] and its phylogenetic relationship to other geminiviruses. Sci Asia 35: 131-136.

9. Ito T, Ogawa T, Samretwanich K, Sharma P, Ikegami M (2008) Yellow leaf curl disease of pumpkin in Thailand is associated with Squash leaf curl China virus. Plant Pathol 57(4): 766.

10. Tsai WS, Shih SL, Lee LM, Wang JT, Duangsong U, Kenyon L (2012) First Report of Bhendi yellow vein mosaic virus associated with yellow vein mosaic of okra (Abelmoschus esculentus) in Thailand. Plant Dis 97(2): 291.

11. Shih S-L, Tsai W-S, Lee L-M, Kenyon L (2013) Molecular Characterization of Begomoviruses Infecting Sauropus androgynus in Thailand. J Phytopathol 161(2): 78-85.

12. Samretwanich K, Chiemsombat $\mathrm{P}$, Kittipakorn $\mathrm{K}$, Ikegami M (2000) A new geminivirus associated with a yellow leaf curl disease of pepper in Thailand. Plant Dis 84(9): 1047.

13. Tsai W, Shih S, Green S, Rauf A, Hidayat S, et al. (2006) Molecular characterization of Pepper yellow leaf curl Indonesia virus in leaf curl and yellowing diseased tomato and pepper in Indonesia. Plant Dis 90(2): 247.

14. Sakata JJ, Shibuya Y, Sharma P, Ikegami M (2008) Strains of a new bipartite begomovirus, Pepper yellow leaf curl Indonesia virus, in leaf-curl-diseased tomato and yellow-vein-diseased ageratum in Indonesia. Arch Virol 153(12): 2307-2313.

15. Koeda S, Kesumawati E, Tanaka Y, Hosokawa M, Doi M, et al. (2016) Mixed infection of begomoviruses on pepper plants at northern Sumatra, Indonesia. Tropic Agri Dev 60(2): 59-64.

16. Tsai WS, Shih SL, Venkatesan SG, Aquino MU, Green SK, et al. (2011) Distribution and genetic diversity of

Chiemsombat $\mathrm{P}$, et al. Begomoviruses Associated to Pepper Yellow Leaf Curl Disease in Thailand. J Agri Res 2018, 3(7): 000183. begomoviruses infecting tomato and pepper plants in the Philippines. Ann Appl Biol 158(3): 275-287.

17. Shih SL, Tsai WS, Lee LM, Wang JT, Green SK, et al. (2010) First Report of Tomato yellow leaf curl Thailand virus associated with pepper leaf curl disease in Taiwan. Plant Dis 94(5): 637.

18. Inoue-Nagata $\mathrm{AK}$, Albuquerque LC, Rocha WB, Nagata $\mathrm{T}$ (2004) A simple method for cloning the complete begomovirus genome using the bacteriophage phi29 DNA polymerase. J Virol Methods 116(2): 209-211.

19. Sambrook J, Russell DW (2001) Molecular cloning: a laboratory manual. $3^{\text {rd }}$ (Edn), Coldspring-Harbour Laboratory Press, UK pp: 2100.

20. Kawata M, Matsumura Y, Oikawa T, Kimizu M, Fukumoto F, et al. (2003) Analysis of DNA extraction buffer components from plant tissue by polymerase chain reaction. Anal Biochem 318: 314-317.

21. Rojas M, Gilbertson RL, Russell DR, Maxwell DP (1993) Use of degenerate primers in the polymerase chain reaction to detect whitefly-transmitted geminiviruses. Plant Dis 77: 340-347.

22. Chenna R, Sugawara H, Koike T, Lopez R, Gibson TJ, et al. (2003) Multiple sequence alignment with the Clustal series of programs. Nucleic acids Res 31(13): 3497-3500.

23. Muhire BM, Varsani A, Martin DP (2014) SDT: a virus classification tool based on pairwise sequence alignment and identity calculation. PLoS ONE 9: e108277.

24. Brown JK, Zerbini FM, Navas-Castillo J, Moriones E, Roberto R-S, et al. (2015) Revision of Begomovirus taxonomy based on pairwise sequence comparisons. Arch Virol 160(6): 1593-1619.

25. Tamura K, Stecher G, Peterson D, Filipski A, Kumar S (2013) MEGA6: Molecular evolutionary genetics analysis version 6.0. Mol Biol Evol 30(12): 27252729.

26. De Barro PJ, Liu S-S, Boykin LM, Dinsdale AB (2011) Bemisia tabaci: a statement of species status. Annu Rev Entomol 56: 1-19.

27. Frohlich D, Torres-Jerez I, Bedford ID, Markham P, Brown JK (1999) A phylogeographical analysis of the Bemisia tabaci species complex based on 


\section{Open Access Journal of Agricultural Research}

mitochondrial DNA markers. Mol Ecol 8(10): 16831691.

28. Boykin LM, Shatters RG, Rosell RC, McKenzie CL, Bagnall RA, et al. (2007) Global relationships of Bemisia tabaci (Hemiptera: Aleyrodidae) revealed using Bayesian analysis of mitochondrial COI DNA sequences. Mol Phylogenet Evol 44(3): 1306-1319.

29. Lapidot M (2007) Screening for TYLCV-resistant plants using whitefly-mediated inoculation. Tomato yellow leaf curl virus disease, pp: 329-342.

30. Xie Y, Zhou X, Zhang Z, Qi Y (2002) Tobacco curly shoot virus isolated in Yunnan is a distinct species of begomovirus. Chin Sci Bull 47(3): 199-201.

31. Li ZH, Zhou PX, Xie ZY (2004) Molecular characterization of tomato-infecting begomoviruses in Yunnan, China. Arch Virol 149(9): 1721-1732.

32. Kumar RV, Singh AK, Singh AK, Yadav T, Basu S, et al. (2015) Complexity of begomovirus and betasatellite populations associated with chilli leaf curl disease in India. J Gen Virol 96(10): 3143-3158.

33. Trisno J, Hidayat SH, Habazar T, Manti I, Jamsari (2009) Detection and Sequence Diversity of Begomovirus Associated with Yellow Leaf Curl Disease of Pepper (Capsicum annuum) in West Sumatra, Indonesia. Microbiol Indonesia 3(2): 56-61.
34. Jamsari J, Pedri J (2013) Complete Nucleotide Sequence of DNA A-like Genome and DNA-A of monopartite Pepper yellow leaf curl virus, A dominant begomovirus infecting Capsicum annuum in West Sumatra Indonesia. Asian J Plant Pathol 7(1): 1-14.

35. Firdaus S, Vosman B, Hidayati N, Jaya Supena ED, Visser RG, et al. (2013) The Bemisia tabaci species complex: additions from different parts of the world. Insect Sci 20(6): 723-733.

36. Götz M, Winter S (2016) Diversity of Bemisia tabaci in Thailand and Vietnam and indications of species replacement. J Asia-Pac Entom 19(2): 537-543.

37. Morilla G, Janssen D, García-Andrés S, Moriones E, Cuadrado IM, et al. (2007) Pepper (Capsicum annuum) is a dead-end host for Tomato yellow leaf curl virus. Phytopathol 95(9): 1089-1097.

38. Polston JE, Cohen L, Sherwood TA, Ben-Joseph R, Lapidot M (2006) Capsicum species: symptomless hosts and reservoirs of Tomato yellow leaf curl virus. Phytopathol 96(5): 447-452.

39. Srinivasan R, Hsu YC, Kadirvel P, Lin MY (2013) Analysis of Bemisia tabaci (Hemiptera: Aleyrodidae) Species complex in Java, Indonesia based on mitochondrial cytochrome oxidase I sequences. Philipp Agric Sci 96(3): 290-295.

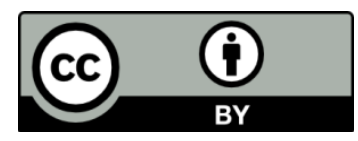

